\title{
PERBEDAAN POLA PENGAMBILAN ENZIM LAKTOPEROKSIDASE DENGAN MENGGUNAKAN METODE KROMATOGRAFI
}

\section{PATTERN DIFFERENCES OF LACTOPEROXIDASE ENZYME IMOBILIZE USE CHROMATOGRAPHY METHOD}

\author{
Hidayah, N., A. N. Al-Baarri, dan C. Budiarti \\ Fakultas Peternakan dan Pertanian, Universitas Diponegoro \\ Kampus Tembalang, Semarang 50275 - Indonesia \\ Email :nurhidayahsholeha@gmail.com
}

\begin{abstract}
The research was carried out to get a method which used as measuring rod of lactoperoxidase (LPO) imobilized, based on reduction of milk fat content by using chromatography and SP Sepharose Fast Flow resin $(S P-F F)$. The study was conducted by using two treatments, a reduction from the fat content before coagulation of casein by rennet (T1), and after coagulation of casein by rennet (T2). The results showed that the T1 produced higher quality than T2. Differences resulting volume of raw materials was possible because of differences in total casein, non-fatsolids, and moisture content in each sample. Differences of LPO immobilization time scales was possible because containt of non-fatsolids in each raw material. High or lowprotein content was influenced by differences in the origin of raw materials LPO medium. While high-low activity LPO influenced the non evenness LPOLPO attached to the resinSP-FF, also was possible because of the extent of sediment total nonfatsolids that can not be separated from raw materials LPO during immobilization.
\end{abstract}

Keywords: chromatography, enzyme activity, lactoperoxidase, whey

\begin{abstract}
ABSTRAK
Penelitian ini bertujuan untuk mencari cara atau metode yang dapat dijadikan panduan dalam pengambilan laktoperoksidase (LPO),berdasarkan cara pengurangan kadar lemak susu dengan menggunakan metode kromatografi dan resinSP Sepharose Fast Flow (SP-FF). Penelitian dilakukan dengan menggunakan dua perlakuan yaitu pengurangan kadar lemak sebelum koagulasi kasein oleh rennet(T1) dan setelah koagulasi kasein oleh rennet (T2). Hasil penelitian menunjukkan bahwa $T_{1}$ menghasilkan kualitas lebih tinggi daripada $T_{2}$. Perbedaan volume bahan baku yang dihasilkan dimungkinkan karena adanya perbedaan total kasein, bahan padat tanpa lemak, dan kadar air yang terkandung dalam susu pada masing-masing sampel. Rentang waktu imobilisasi LPO berbeda, diduga karena perbedaan kandungan bahan padat tanpa lemak (BPTL) dalam masing-masing bahan baku. Tinggi rendahnya kadar protein dipengaruhi oleh perbedaan medium asal bahan baku LPO. Sedangkan tinggi-rendahnya aktivitas LPO selain dipengaruhi ketidakrataan LPO yang menempel pada resin SP$\mathrm{FF}$, juga diduga oleh pengaruh banyak sedikitnya endapan BPTL yang tidak dapat terpisah dari bahan baku LPO selama immobilisasi.
\end{abstract}

Kata Kunci : aktivitas enzim, kromatografi, laktoperoksidase, whey

\section{PENDAHULUAN}

Salah satu komponen bioaktif protein susu adalah enzim laktoperoksidase (LPO). LPO telah dikomersialkan karena memberikan banyak manfaat dan memiliki nilai ekonomi tinggi dalam bidang pangan, kesehatan dan industri. Aplikasi LPO di Indonesia masih dalam tahap pengembangan karena hingga saat ini belum ada metode praktis yang digunakan untuk mengambil LPO dari dalam susu. Selama ini, LPO didapatkan dari whey sehingga proses konversi susu menjadi whey harus dilakukan dan membutuhkan tahapan proses yang panjang. Prinsip pengambilan LPO yaitu dengan memanfaatkan teknologi imobilisasi dengan menggunakan resin SPSepharose Fast Flow (SP-FF) dan bahan baku LPO yang berasal dari whey, hasilnya LPO dapat menempel pada resin dan dapat dengan mudah untuk dipisahkan atau diambil. Istilah pengambilan enzim sering disebut imobilisasi enzim.

Dalam upaya mendapatkan LPO dengan aktivitas tinggi, maka lemak yang ada di dalam susu perlu untuk diminimalisir. Jika lemak yang terdapat di dalam susu tidak dihilangkan maka akan berpotensi menghambat aktivitas LPO. Pemisahan lemak dan skim susu yang lazim dilakukan adalah dengan menggunakan metode sentrifugasi. Metode ini umumnya 
dilaksanakan pada saat kasein susu akan dikoagulasikan. Namun, oleh karena terbatasnya alat sentrifuge, maka pemisahan lemak dengan menggunakan alat ini perlu diusahakan seefisien mungkin terutama karena kapasitas alat sentrifugasi yang terbatas.

Tujuan penelitian adalah untuk mencari cara atau metode yang dapatdijadikan panduan dalam pengambilan LPO, berdasarkan cara pengurangan kadar lemak susu dengan menggunakanmetode kromatografi dan resinSP Sepharose Fast Flow (SP-FF).Manfaat penelitian untuk menginformasikan kepada pembaca tentang metode yang praktis dan tepat dalam pengambilan LPO.

\section{METODE PENELITIAN}

\section{Bahan dan Alat}

Bahan yang digunakan dalam penelitian adalah susu segar masing-masing perlakuan 2 liter, resin SP Sepharose Fast Flow (SP-FF) 50 g, aquades, asam laktat, rennet, $1 \mathrm{M} \mathrm{NaCl}$ dalam aquades $300 \mathrm{ml}, 0,4$ $\mathrm{M} \mathrm{NaCl}$ dalam 0,1 M PB (phospate buffer), alkohol 20\%, larutan ABTS dalam $10 \mathrm{mM}$ asetat buffer. Peralatan digunakan adalah sentrifuge, microtube ukuran $15 \mathrm{ml}$, inkubator, beaker glass, kuvet, kolom silinder, kain saring dengan ukuran $30 \mathrm{~cm} \mathrm{x}$ $30 \mathrm{~cm}$, pendingin, spektrofotometer.

\section{Tahapan Penelitian}

\section{Pembuatan Bahan Baku LPO}

Bahan baku LPO didapatkan dengan cara menggunakan dua perlakuan. Perlakuan I yaitu pengurangan kadar lemak sebelum koagulasi kasein oleh rennet (T1). Pertama, tahap pengumpulan susu. Susu segar sebanyak 2 liter didapatkan dari peternakan milik Fakultas Peternakan Universitas Diponegoro. Kedua, tahap sentrifugasi. Susu segar disentrifugasi dengan kecepatan 6000 rpm selama 10 menit untuk memisahkan antara krim (lemak) dan skim.

Ketiga, tahap pembuatan whey dengan cara menambahkan rennet dan asam laktat ke dalam susu. Selanjutnya, susu yang telah tercampur dengan rennet dan asam laktat dimasukkan ke dalam inkubator.
Tunggu selama 40 menit agar terbentuk koagulasi kasein, lalu disaring menggunakan kain saring ukuran. Air yang keluar disebut whey sedangkan padatannya disebut curd.

Perlakuan II adalah pengurangan kadar lemak setelah koagulasi kasein oleh rennet (T2). Pertama, tahap pengumpulan susu. Kedua, tahap pembuatan whey. Ketiga, tahap sentrifugasi susu. Proses pada tahap pengumpulan susu, pembuatan whey maupun sentrifugasi susu sama seperti proses perlakuan I. Setelah perlakuan I dan II maka masing-masing perlakuan dilanjutkan dengan tahap imobilisasi yang akan menghasilkan LPO.

\section{Imobilisasi LPO}

Pelaksanaan imobilisasi dilakukan pada dalam pendingin bersuhu $4^{0} \mathrm{C}$. Sebelum kolom digunakan harus dilakukan preparasi. Preparasi kolom diawali dengan mengalirkan aquades $300 \mathrm{ml}$ ke dalam kolom. Hasil aliran dibuang. Selanjutnya kolom dialiri penyerap berupa resin. Resin SP-FF dialirkan ke dalam kolom hingga memampat. Resin yang telah memampat dalam kolom segera dialiri pelarut berupa $1 \mathrm{M} \mathrm{NaCl}$ dalam aquades sebanyak $300 \mathrm{ml}$. Hasil aliran dibuang. Kolom kembali dialiri dengan menggunakan aquades sebanyak $300 \mathrm{ml}$, larutan yang keluar dibuang. Kolom siap digunakan.

Kolom yang telah berisi resin yang memampat, segera dialiri pelarut berupa bahan baku LPO.Pelarut dialirkan ke dalam kolom dan hasil aliran dibuang karena tidak mengandung LPO. Selanjutnya kolom dialiri $0,4 \mathrm{M} \mathrm{NaCl}$ dalam 0,1 M PB. Hasil aliran yang kemudian ditampung dalam microtube dengan volume $10 \mathrm{ml}$ dan diberi label dan disimpan pada pendingin. Selanjutnya, masing-masing microtube diukur kadar protein dan aktivitas enzim.

\section{Pengukuran Nilai Absorbansi}

\section{Pengukuran Kadar Protein}

Identifikasi kadar protein dilakukan menggunakan spektrofotometer pada panjang gelombang $280 \mathrm{~nm}$ (Harborne, 1987). Untuk mendapatkan nilai kadar protein terlarut, maka nilai absorbansi yang didapatkan dari pengukuran dikonversikan.

Pengukuran Aktivitas LPO 
Penentuan aktivitas LPO dilakukan dengan menggunakanABTS sebagai substratdibaca pada panjang gelombang $(\lambda) 412 \mathrm{~nm}$ (Bardsley, 1985)

\section{HASIL DAN PEMBAHASAN}

\section{Bahan Baku LPO}

Penelitian ini menggunakan susu segar sebagai sumber bahan baku LPO. Pengambilan LPO pada penelitian dilakukan dengan sentrifugasi dan pembuatan whey. Perlakuan pada penelitian ini terletak pada pengurangan kadar lemak, yaitu $T_{1}$ adalah sentrifugasi dilanjut pembuatan whey. Sedangkan $\mathrm{T}_{2}$ adalah proses pembuatan whey dilanjutkan sentrifugasi. Susu segar yang diperoleh dari peternakan disentrifugasi dengan kecepatan 6000 rpm selama 10 menit. Dengan demikian, antara krim dan skim terpisah, lalu krim dibuang. Hal ini sesuai dengan pendapat Suhartono (1989) bahwa pemisahan krim susu dapat dilakukan dengan menggunakan sentrifuge. Prinsip kerja sentrifuge adalah penerapan gaya sentrifugal dengan cara pemusingan (sentrifugasi) untuk memisahkan partikel berdasarkan densitas atau bobot jenisnya. Krim akan terakumulasi di bagian atas sedangkan skim akan mengendap di bagian bawah.

Penelitian ini menggunakan whey dengan cara menambahkan $0,25 \mathrm{ml}$ rennet dan asam laktat secukupnya. Rennet berfungsi untuk mengkoagulasikan kasein sedangkan asam laktat berfungsi untuk membantu proses koagulasikasein oleh rennet. Hal ini sesuai dengan pendapat Schwimmer (1981) bahwa rennet merupakan bahan bioaktif yang awalnya merupakan hasil ekstraksi abomasum sapi muda yang digunakan sebagai starter dalam proses pembuatan keju, karena mengandung enzim khimosin dengan kadar tinggi.

Kasein yang telah terkoagulasi selanjutnya dipotong-potong sehingga mengeluarkan cairan. Cairan yang keluar dari hasil pemotongan tersebut adalah whey sedangkan padatannya disebut curd. Hal ini sesuai dengan pendapat Korhonen dan Pihlanto-Leppälä (2004) bahwa kasein yang terkoagulasi akan membentuk curd. Curd cenderung akan mengalami sineresis yaitu suatu kontraksi untuk mengeluarkan cairan yang disebut whey. Volume whey yang dihasilkan dari masing-masing perlakuan kemudian diukur. Perlakuan pertama $\left(\mathrm{T}_{1}\right)$ dan perlakuan kedua $\left(\mathrm{T}_{2}\right)$ ternyata menghasilkan volume yang berbeda.Perbedaan volume bahan baku LPO dari kedua perlakuan ditunjukkan pada Tabel 1.

Tabel 1. Perbedaan volume bahan baku LPO

\begin{tabular}{ccc} 
No. & Perlakuan & $\begin{array}{c}\text { Volume Bahan Baku } \\
\text { LPO }(\mathrm{ml})\end{array}$ \\
\hline 1. & $\mathrm{~T}_{1}$ & 1800 \\
2. & $\mathrm{~T}_{2}$ & 1780 \\
\hline
\end{tabular}

Berdasarkan Tabel 1, diketahui bahwa volume bahan baku LPO pada $T_{1}=1800 \mathrm{ml}$ sedangkan $\mathrm{T}_{2}=1780 \mathrm{ml}$. Volume bahan baku yang dihasilkan dari dua macam perlakuan tersebut, adalah berbeda dimungkinkan karena adanya perbedaan total kasein, bahan padat tanpa lemak (BPTL), dan kadar air yang terkandung dalam susu pada masingmasing sampel. Hal ini sesuai dengan pendapat Fox dan Mc Sweeney (1998), dan Fox (2003) bahwa komponen penyusun susu masing-masing individu sangat bervariasi. Variasi tersebut dapat terjadi akibat pengaruh berbagai faktor diantaranya spesies, bangsa, kondisi kesehatan, pakan, tingkat laktasi dan umur yang berbeda.

\section{Imobilisasi LPO}

Dalam penelitian ini, kolom silinder yang telah terpasang pada penyangga kromatografi, segera dialiri resin SP-FF sampai memampat, segera dialiri bahan baku LPO. Pelarut dialirkan ke dalam kolom dan hasil aliran dibuang karena tidak mengandung LPO. Selanjutnya kolom dialiri $0,4 \mathrm{M} \mathrm{NaCl}$ dalam $0,1 \mathrm{M}$ PB yang berfungsi untuk memisahkan protein yang bermuatan positif dengan resin yang bermuatan negatif. LPO keluar dan hasilnya ditampung dalam microtube dengan volume masing-masing microtube $10 \mathrm{ml}$. Pemisahan protein berdasarkan cara ini adalah sesuai dengan Winarno (2002) bahwa protein-protein yang bermuatan positif dalam kolom kromatografi dapat dikeluarkan dengan penambahan garam 
$\mathrm{NaCl}$ atau garam lain pada larutan buffer yang digunakan untuk mengeluarkan enzim.

Dalam penelitian ini, bahan baku LPO yang dialirkan ke dalam kolom membutuhkan waktu yang berbeda dalam menghasilkan LPO. Perbedaan rentang waktu imobilisasi LPO dariT dan $_{2}$ ditunjukkan pada Tabel 2 .

Tabel 2. Rentang Waktu Imobilisasi

\begin{tabular}{ccc}
\hline No. & Perlakuan & $\begin{array}{c}\text { Rentang Waktu } \\
\text { Imobilisasi }\end{array}$ \\
\hline 1. & $\mathrm{~T}_{1}$ & $20.00-03.00$ \\
2. & $\mathrm{~T}_{2}$ & $19.45-03.00$ \\
\hline
\end{tabular}

Berdasarkan Tabel 2, menunjukkan bahwa perlakuan I $\left(\mathrm{T}_{1}\right)$ membutuhkan waktu imobilisasi untuk menghasilkan LPO selama 8 jam dari pukul 20.00-03.00 sedangkan perlakuan II $\left(\mathrm{T}_{2}\right)$ selama 8 jam 15 menit yang dimulai dari pukul 19.45-03.00. $\mathrm{T}_{1}$ membutuhkan waktu imobilisasi lebih singkat meskipun volume bahan baku LPO lebih tinggi daripada $\mathrm{T}_{2}$. Rentang waktu imobilisasi LPO yang digunakan pada $T_{2}$ berlangsung lambat, diduga karena kandungan bahan padat tanpa lemak (BPTL) lebih banyak sehingga membutuhkan proses yang lama untuk menghasilkan LPO.

\section{Kadar Protein}

Absorbansi setiap microtube diukur pada panjang gelombang $(\lambda) 280 \mathrm{~nm}$. Pengukuran ini dilakukan dengan tujuan mengetahui kadar protein. Kurva absorbansihasil imobilisasi pada $\mathrm{T}_{1}$ dan $\mathrm{T}_{2}$ ditunjukkan pada Gambar 1.

Berdasarkan kurva Gambar 1, $\mathrm{T}_{1}$ dan $\mathrm{T}_{2}$ menunjukkan kadar protein semakin menurun seiring bertambahnya nomor microtube. Kadar protein relatif tinggi pada fraksi awal yaitu microtube nomor 1 sampai 8, kemudian mulai microtubenomor 9 kandungan kadar protein berangsur-angsur menurun dan hanya mengalami sedikit kenaikan. Kromatografi yang digubakan dalam penelitian ini, merupakan pemisahan molekul menurut berat molekulnya. Saat bahan baku LPO dialirkan ke dalam kolom maka partikel dengan ukuran besar akan bergerak turun lebih cepat dari partikel yang berukuran kecil karena partikel besar bergerak turun tanpa melalui pori-pori resin.
Hal ini sesuai dengan penelitian yang dilakukan oleh Touch et al., (2004) bahwa protein mempunyai berat molekul besar sehingga lebih dahulu diserap dan lebih dahulu keluar.

Berdasarkan kurva Ilustrasi $1, \mathrm{~T}_{1}$ dan $\mathrm{T}_{2}$ memiliki perbedaan pada nilai kadar protein. Nilai kadar protein yang dihasilkan $\mathrm{T}_{1}$ lebih tinggi daripada $\mathrm{T}_{2}$. Nilai kadar protein tertinggi pada $\mathrm{T}_{1}=4,290 \%$ sedangkan $\mathrm{T}_{2}=3,723 \%$. Nilai kadar protein terendah pada $\mathrm{T}_{1}=0,213 \%$ sedangkan $\mathrm{T}_{2}=0,130 \%$. Faktor yang mempengaruhi tinggi rendahnya kadar protein adalah perbedaan medium asal bahan baku LPO. Bahan baku LPO pada $\mathrm{T}_{1}$ didapatkan dengan cara sentrifugasi dilanjut dengan pembuatan whey adalah cara yang lazim digunakan. Cara ini juga sama seperti yang dilakukan oleh Touch et al., (2004) sehingga mendapatkan kadar protein relatif tinggi karena LPO adalah enzim yang terdapat di dalam whey dengan kadar tertinggi. Sementara bahan baku pada $T_{2}$ didapatkan dengan perlakuan yang berbeda dengan $\mathrm{T}_{1}$ sehingga kadar protein yang didapatkan relatif rendah. Hal ini dimungkinkan karena sentrifugasi yang dilakukan pada $T_{2}$ adalah sentrifugasi dengan muatan rendah, artinya LPO dimungkinkan terkonsentrasi di dekat axis (microtube bagian atas) dan tidak ikut terambil untuk proses selanjutnya karena muatan komponen lain didalam sampel seperti kasein dan lemak, telah diambil melalui proses sebelumnya.

\section{Aktivitas LPO}

Aktivitas LPO diukur dengan menggunakan spektrofotometer pada panjang gelombang $(\lambda) 412 \mathrm{~nm}$. Hal ini sesuai dengan pendapat Bardsley (1985) bahwa LPO mempunyai absorbansi maksimum 412. Kurva nilai aktivitas laktoperoksidase (LPO) pada $\mathrm{T}_{1}$ dan $\mathrm{T}_{2}$ ditunjukkan pada Gambar 2 .

Kurva Gambar 2 perlakuan I $\left(\mathrm{T}_{1}\right)$, didapatkan hasil bahwa tidak semua microtube padaT $_{1}$ memiliki aktivitas LPO. Microtube yang memiliki aktivitas LPO hanya 10 microtube dari 29 yang diukur absorbansinya yaitu pada nomor $1 ; 4 ; 5 ; 6 ; 8$; $10 ; 11 ; 12 ; 13 ; 15 ;$ dan 16 . Puncak tertinggi terdapat pada microtube 4; 8 dan 12 . 


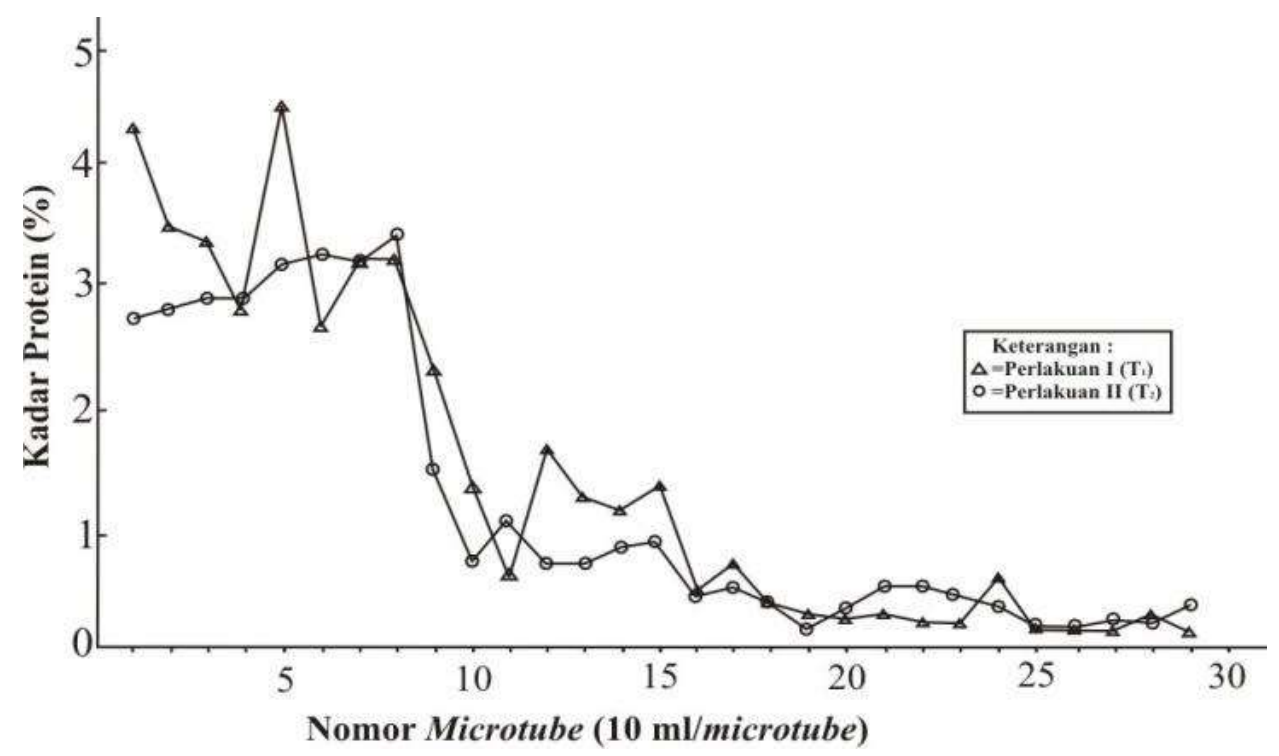

Gambar 1. Kurva Nilai Kadar Protein pada absorbansi $280 \mathrm{~nm}$ dengan menggunakan spektrofotometer

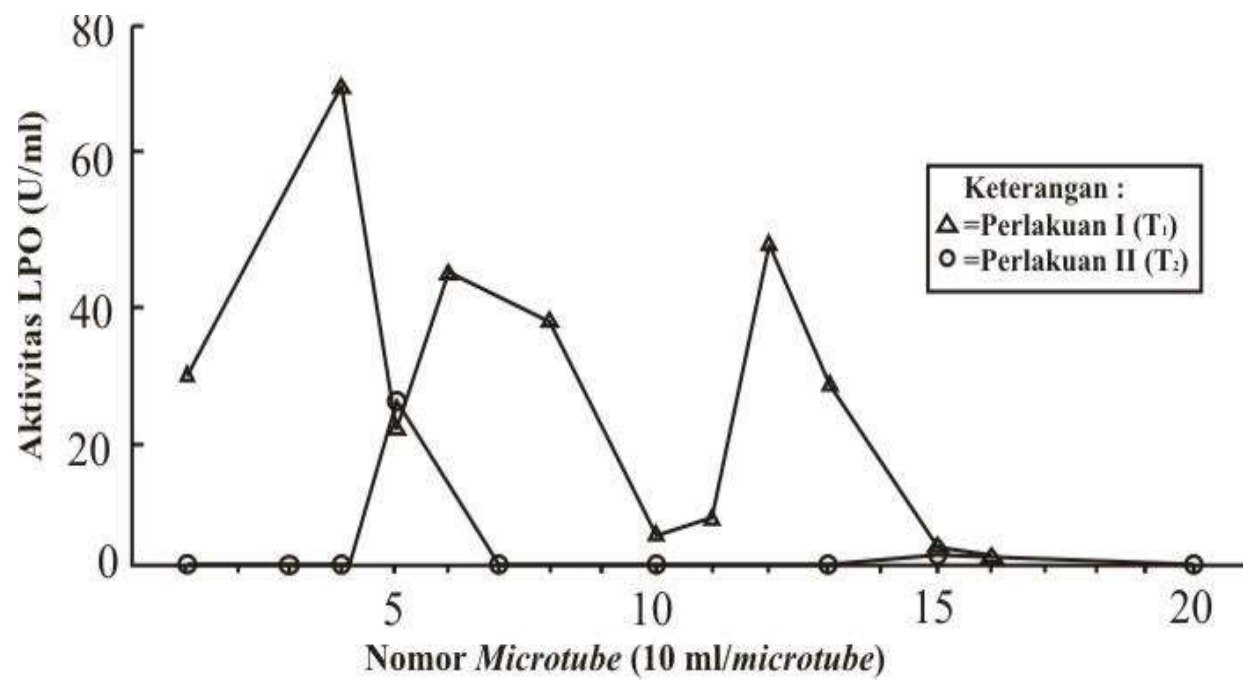

Gambar 2. Kurva Hasil ABS (absorbansi) 412 nm dengan menggunakan spektofotometer

Sedangkan microtube $1 ; 5 ; 6 ; 10 ; 13 ; 15 ;$ dan 16 memiliki aktiitas LPO yang relatif rendah.

Kurva Gambar 2 perlakuan II $\left(\mathrm{T}_{2}\right)$, didapatkan hasil bahwa aktivitas LPO dari 29 microtube hanya ada pada microtube nomor tertentu, yaitu microtube nomor 5 dan 15 sedangkan microtube nomor lainnya tidak terdapat aktivitas LPO.

Nilai aktivitas LPO tertinggi pada $\mathrm{T}_{1}$ maupun $\mathrm{T}_{2}$ berada pada microtube awal yaitu $\mathrm{T}_{1}$ microtube nomor 5 sedangkan $\mathrm{T}_{2}$ microtube nomor 2.

Kurva $\mathrm{T}_{1}$ dan $\mathrm{T}_{2}$ memiliki perbedaan yaitu sebanyak 11 microtube pada $\mathrm{T}_{1}$ memiliki aktivitas LPO sedangkan $\left(\mathrm{T}_{2}\right)$ hanya 2 microtube. Perbedaan mengenai tinggi- rendahnya aktivitas LPO disebabkan resin SP-FF adalah jenis resin penukar ion sehingga dapat menarik ion yang berlawanan. Bahan baku LPO menempel pada resin tersebut secara tidak merata dan turun berupa pita dengan laju aliran yang berbeda dan mengalir keluar kolom sehingga aktivitas yang dihasilkan juga berbeda. Hal ini sesuai dengan pendapat Gritter et. al., (1991) bahwa dalam imobilisasi, kolom kromatografi dibuat dengan cara menuangkan lumpuran atau suspensi fase diam dalam pelarut yang sesuai ke dalam kolom dan dibiarkan memampat atau mengalir. Komponen yang diinginkan akan turun/keluar dengan laju aliran yang berlainan. 
Dalam penelitian ini, diduga banyak sedikitnya endapan total bahan padat tanpa Lemak (BPTL) yang tidak dapat terpisah dari bahan baku LPO selama imobilisasi juga dapat mempengaruhi tinggi-rendahnya aktivitas LPO. Total BPTL $\mathrm{T}_{1}$ lebih rendah daripada $T_{2}$. Hal ini karena partikel pada $T_{1}$ terpisah secara sempurna pada saat pembuatan bahan baku LPO sehingga saat imobilisasi lemak dapat dipisahkan dengan baik.

\section{KESIMPULAN}

Berdasarkan hasil penelitian yang dilakukan dapat disimpulkan bahwa $\mathrm{T}_{1}$ adalah metode yang dapat dijadikan panduan dalam pengambilan enzim LPO dari susu sapi karena menghasilkan kadar protein serta aktivitas LPO yang lebih tinggi daripada $T_{2}$.

\section{DAFTAR PUSTAKA}

Bardsley, W. G. 1985. Steady-state kinetics of lactoperoxidasecatalyzed reaction. In K. M. Pruitt, and J. O. Tenovuo (Eds.), The lactoperoxidase system: Chemistry and biological significance (pp. 55-87). New York: Marcel Dekker.

Daulay, D. 1991. Fermentasi Keju. Pusat Antar Universitas Pangan dan Gizi. Institut Pertanian Bogor, Bogor.

Fox, PF., and Mc Sweeney PLH. 1998. Dairy Chemistry and Biochemistry. London: Blackie Academic and Profesional.

Fox, PF. 2003. The major constituents of milk. Di dalam: Smit G, editor. Dairy Processing Improving Quality. Boston: CRC Press LLC.

Gritter, J.R., Bobbit, J.M. and Schwarting, A. E. 1991. Pengantar Kromatografi Edisi Kedua. Bandung. ITB. 107-109, 140147, 160-163.

Harborne, J.B. 1987. Metode Fitokimia. Penerbit ITB. Bandung.

Korhonen, H., and Pihlanto-Leppälä, A. 2004. Milk - Derived Bioactive Peptides: Formation and Prospects for Health Promotion. In: Handbook of Functional Dairy Products C. Shortt and J. O'
Brien(eds). CRC Press, Boca Raton, FL, pp. $109-124$.

Schwimmer. 1981. Sources of Food Enzymology. Wesport Connecticut : The Avi Pub. Co. Inc.

Suhartono, M.T. 1989. Enzim dan Bioteknologi. Direktorat Jenderal Pendidikan Tinggi Antar Universitas Bioteknologi, Institut Pertanian Bogor. 172-220.

Touch, V., S. Hayakawa, S. Yamada, dan S. Kaneko. 2004. Effects of a lactoperoxidase-thiocyanate-hydrogen peroxide system on Salmonella enteritidis in animal or vegetable foods. 2004. International Journal of Food Microbiology 93, 175- 183.

Winarno, FG. 2002. Kimia pagan dan gizi. Gramedia pustaka utama. Jakarta. 